\title{
UNDERSTANDING KNOWLEDGE SHARING BEHAVIOR: AN EXAMINATION OF THE EXTENDED MODEL OF THEORY OF PLANNED BEHAVIOR
}

\author{
Sabrina O. Sihombing \\ Business School, University of Pelita Harapan \\ UPH Building F, Lippo Karawaci, Jln. MH Thamrin Boulevard 1100, Tangerang 15811 \\ sabrinasihombing@hotmail.com
}

\begin{abstract}
Knowledge is recognized as one valuable asset for many organizations. Thus, knowledge-sharing is one of important activities in many organizations, including university. Knowledge sharing is defined as activities of transferring or disseminating organizationally relevant information, ideas, suggestions, and expertise with one another. This research applied Christian values as a moderating variable in the framework of theory of planned behavior. The aims of this research to assess applicability of the theory of planned behavior to predict knowledge sharing and to examine the effects of Christian values in the relationship between attitude and intention to share knowledge. A self-administered questionnaire was used to collect the data for this study. The data was then analyzed using structural equation modeling.
\end{abstract}

Keywords: knowledge sharing, theory of planned behavior, Christian values, faculty

\begin{abstract}
ABSTRAK
Pengetahuan adalah sebuah asset berharga bagi banyak organisasi. Karenanya, pembagian pengetahuan merupakan aktivitas penting bagi banyak organisasi, termasuk di universitas. Pembagian pengetahuan didefinisikan sebagai aktivitas transfer atau diseminasi informasi relevan, ide, saran, dan keahlian antara satu dengan yang lain. Penelitian ini dihubungkan dengan nilai-nilai Kristen sebagai variabel moderasi rangka kerja dari teori planned behavior. Tujuan penelitian ini yaitu untuk mengakses aplikasi teori planned behavior untuk memprediksikan pembagian pengetahuan dan untuk memeriksa efek nilai-nilai Kristen dalam hubungannya dengan sikap dan intensi dalam pembagian pengetahuan. Kuesioner yang dibagikan yaitu untuk mengumpulkan data penelitian, yang kemudian dianalisis menggunakan structural equation modeling.
\end{abstract}

Kata kunci: pembagian pengetahuan, teori planned behavior, nilai-nilai Kristen, fakultas 


\section{INTRODUCTION}

\section{Background to the Research Problem}

Knowledge is important. Knowledge is recognized as one valuable asset for many organizations. Thus, knowledge-sharing is one of important activities in many organizations, including university. Knowledge sharing is defined as activities of transferring or disseminating organizationally relevant information, ideas, suggestions, and expertise with one another (Bartol \& Srivastava, 2002). This activity can enhance not only knowledge of the person who owns but also others that are given or transformed the knowledge by that person (Halal, 2008; Gurteen, 1999).

Sharing is one important value for Christian believers. A verse from a Holy Bible stated that "Give and it shall be given unto you" (Luke 6:38). God also pointed out that when we give something to other people means that we do something to Him, as verses from Holy Bible stated "For I was an hungered, and ye gave me meat: I was thirsty and ye gave me drink: I was a stranger, and ye took me in: Naked, and ye clothed me: I was sick, and ye visited me: I was in prison, and ye came unto me...Verily I say unto you, Inasmuch as ye have done it unto one of the least of these my brethren, ye have done it unto me" (Matthew 25:35, 36, and 40, emphasis added).

There are many researches about knowledge sharing, for examples Lin (2007), Yang \& Chen (2007), Yuen \& Majid (2007), De Vries et al. (2006), Burgess (2005), Bartol \& Srivastava (2002). However, empirical studies regarding the influence of religiosity, especially in Christianity context, on knowledge sharing behavior have been rarely conducted. Therefore, this research applied the theory of planned behavior (TPB) by incorporating Christian values as moderating variable of the relationship between attitude and intention to share knowledge.

\section{Justifications to the Research}

This research can be justified on these two grounds as follows: (1) the importance of moderating variable for theory contribution, and (2) potential outcomes for practice.

\section{The Importance of Moderating Variable for Theory Contribution}

The research model applied in this research is the extension of the theory of planned behavior (TPB) which was developed Ajzen (1988). The TPB has been applied to various contexts of people behaviors. For example, the TPB was applied in many fields such as organizational behavior (Cordano \& Frieze, 2000; Morris \& Venkatesh, 2000; Maurer \& Palmer, 1999), complain behavior (East, 2000), research dissemination (Breslin et al., 2001), proenvironmental behavior (Oreg \& Katz-Gerro, 2006; Cheung et al., 1999; Stern et al., 1995), and purchase behavior (Tarkiainen \& Sundqvist, 2005; George, 2002; Dharmmesta \& Khasanah, 1999; Kalafatis et al., 1999; Kokkinaki, 1999; Kanler \& Todd, 1998; Thompson \& Thompson, 1996). This research applied the theory of planned behavior (TPB) by incorporating Christian values as moderating variable of the relationship between attitude and intention to share knowledge as Ajzen (2001) pointed out the need to understand factors that moderate the effects of attitudes and intentions as: "Although it is now generally recognized that attitudes are relevant for understanding and predicting social behavior, many question remain. Investigators continued to identify factors that moderate the effects of attitudes and intentions on overt behavior" (p.48) and "From a theoretical perspective, moderating variables can enhance our understanding of psychological processes involved in going from general dispositions to specific actions" (p.69). 
This research adds Christian values in the framework of the theory of planned behavior. The adding of Christian values is based on the understanding that the need to integrate faith and work in our daily lives (Riady, 2008). Furthermore, according to several researchers, religion's influence in human behavior remains under researched (Jusmaliani \& Nasution, 2009; Lindridge, 2005; Arnould et al., 2005; Wells \& Prensky, 1996; Delener, 1994).

\section{Potential Outcomes for Practices}

In practices, researcher hopes this study could offer understanding on factors that influence knowledge-sharing behavior, especially in Christianity context. The understanding of those factors may give inputs to the Christian university to help and maintain their faculty members to conduct knowledge-sharing activities.

\section{Literature Review}

\section{Knowledge and Knowledge Sharing}

Knowledge is defined as "a fluid mix of framed experience, values, contextual information, and expert insights that provides a framework for evaluating and incorporating new experiences and information" (Davenport \& Prusak cited by Ipe, 2003). In other words, it can be stated that knowledge refers to the fact or condition of knowing something gained through experience.

There are 12 characteristics of knowledge (Halal, 2008). Those characteristics are: (1) created by anyone, (2) acts as a fluid, (3) organized hierarchically, (4) reduces conflict, (5) changes value, (6) distributed cheaply, (7) increases when shared, (8) transmitted in networks, (9) abhors a vacuum, (10) guided by spirit, (11) unique for individuals, and (12) an infinite resource. As stated before, one characteristic of knowledge is increases when shared.

Knowledge is an intangible asset that increases when shared (Halal, 2008). In other words, the owner of knowledge can duplicate this knowledge and share it with others in return for their knowledge. Both parties would then continue to own their original knowledge, while also having the new knowledge they gained, thereby increasing the total amount of knowledge in use (Halal, 2008). This leads to the importance of knowledge sharing.

Lin (2007) defined knowledge sharing as a social interaction culture, involving the exchange of employee knowledge, experiences, and skills through the whole department or organization. Other researchers, for example, Bartol \& Srivastava (2002) and Lee (cited by Pai, 2006) defined knowledge sharing as activities of transferring or disseminating organizationally relevant information, ideas, suggestions, and expertise with one another. Knowledge sharing presumes a relation between at least two parties, one that possesses knowledge and the other that obtain knowledge (Hendriks, 1999). Furthermore, Hendriks also pointed out that the first party should communicate its knowledge, consciously and willingly or not, in some form or other (either by acts, by speech, or in writing). Then, the other party should be able to perceive these expressions of knowledge, and make sense of them (for example, by imitating the acts, by listening, by reading the book).

This research applied TPB in understanding knowledge sharing. The reason is because TPB as a comprehensive theory in understanding human behavior (Cheng, Lam, \& Hsu, 2006). Furthermore, the accumulated evidence shows that TPB is useful in explaining human behavior (Oreg \& KatzGerro, 2006; Tarkiainen \& Sundqvist, 2005; George, 2002; East, 2000; Dharmmesta \& Khasanah, 1999). 


\section{The Theory of Planned Behavior (TBP)}

The theory of planned behavior is a general, parsimonious model that can predict a range of behavior (Corner \& Abraham, 2001). The theory is an extension of the theory of reasoned action (TRA; Azjen \& Fishbein, 1980). The TPB is made necessary by the original model's limitations in dealing with behaviors over which people have incomplete volitional control (Ajzen, 1991). Briefly, the theory postulates that individual's action is influenced by behavioral intention. Behavioral intention is determined by three factors: attitude toward the behavior, subjective norm, and perceived behavioral control (Figure 1). Attitude is defined as people's overall definition of their performing behavior. Subjective norms refer to people's perception of social pressure to perform the behavior. Perceived behavioral control measures how well a person can execute the behavior (Ajzen, 1991).

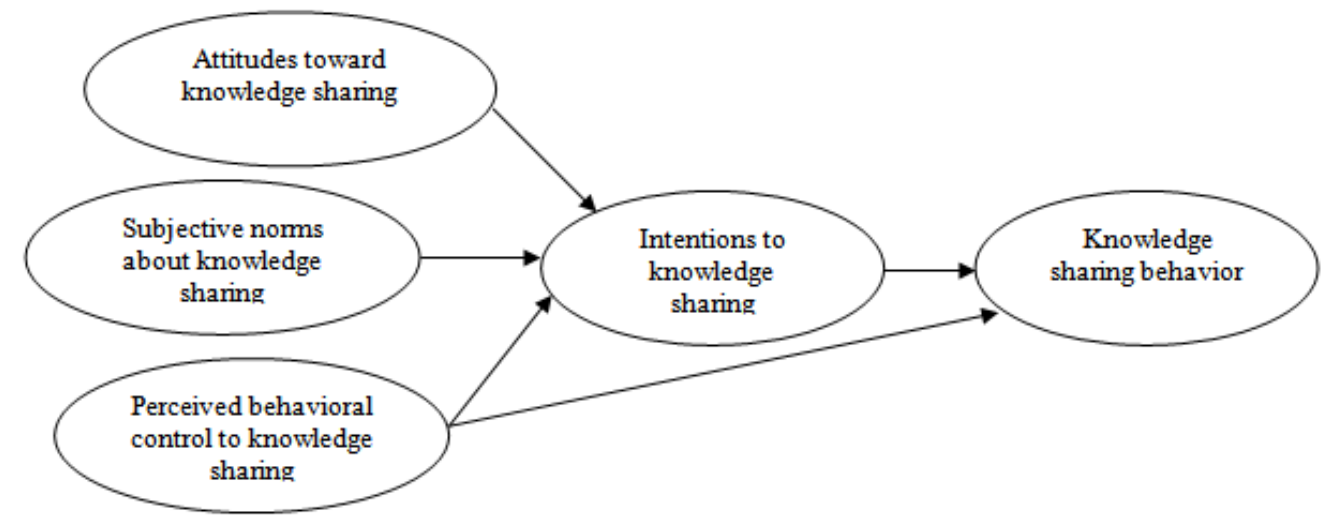

Figure 1 Theory of planned behavior Source: Ajzen (1988)

This research extended theory of planned behavior by adding Christian values as antecedent of attitude toward knowledge sharing.

\section{Values and Christian Values}

Despite value is one important construct in social science research, there is no consensus in the literature about the definition of value (Lombaert, 2003). According to Lombaert (2003) when he examined 4000 articles on values, about 170 definitions of word value emerged. Furthermore, Lombaert also pointed out that value is a vague term which refers to a fundamental aspiration of the human person for living a society. Another researcher, Zetterberg (1998) also pointed out that the term value has many meanings. For example, the term value in market research can be associated with value for money and consumer values.

According to Rokeach (1986), values are defined as a type of belief about how one ought or ought not to behave. The concept of value is one important variable to human life because values influence all aspects of human life (Rokeach, 1973 cited by Wang et al., 1994). Beatty et al. (1988, cited by Wang et al., 1994) also pointed out that values provide clues about how society operates. This is because values are individual's depiction of a society's goals. Hofstede (1994) stated that values are among the first children learned. Since the age of 10, most children have their basic value systems. Values are acquired through the family and neighborhood and later through school (Karahanna et al., 2005). Furthermore, values are stable through generation (de Mooij, 2004; Lombaert, 2003; Hofstede, 1994). In other words, it is likely that the same individual will be consistent in his or her response to a situation. Furthermore, Zetterberg (1998) stated that values are more lasting than attitudes. 
There are five important features of values (Smith \& Schwartz in Chan, 2009). First, values are beliefs. However, values are not objective and cold ideas. Values are activated which they become infused with feeling. Second, values refer to desirable goals. Third, values transcend specific actions and situations. Fourth, values serve as standards to guide the selection or evaluation of behavior, people, and events. Fifth, values are ordered by importance relative to one another. The ordered set of values forms a system of value priorities.

This study used Christian values as a moderating variable in the relationship between people's attitude toward knowledge sharing and intention to share knowledge (Figure 2). Therefore, the sources and definitions of Christian values must be identified. On the other hand, there is no single course on which all agree (Lombaerts, 2003; Scaperlanda, 1993). Lombaert (2003) stated that Christian values can be defined as viewpoints or principles which help to discern the Christian value of (way of valuing) the various aspect of life. The Holy Bible (both the Old and the New Testaments) is the source of Christian values. This research applied a list of ten values or principles for living that are emphasized most strongly in the Bible (hhtp://www.christianbiblereference.org/index.htm). Those values are: (1) worship only God (Mark 12:30), (2) respect all people (Mark 12:31), (3) be humble (Matthew 5:7), (4) be honest (Ephesians 4:25), (5) live a moral life (1 Corinthians 6:19-20), (6) be generous with time and money (Luke 6:38), (7) practice what you preach, don't be a hypocrite (Matthew 23:28), (8) dont'be self-righteous (1 John 1:8), (9) don't hold a grudge (Matthew 5:39), and (10) forgive others (Matthew 6: 14-15).

There are several reasons why Christian values as a moderating variable and not as an antecedent of people attitude toward knowledge behavior. First, though value is the most abstract of the social cognition (Homer \& Kahle, 1988), this research applied specific values, that is, Christian values which should affect in daily life of Christian believers. The second reason is that value can be one factor that interacts with other factors to influence people behavior. Empirical evidence shows that values can be treated as a moderating variable (Ismail et al, 2009a; Ismail et al., 2009b).

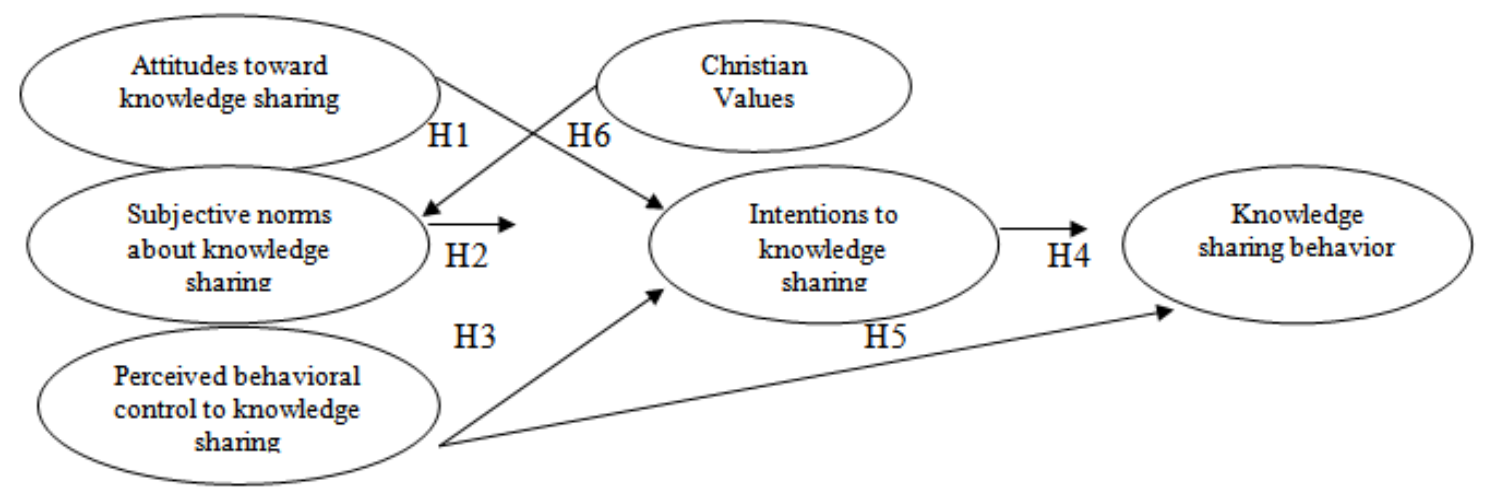

Figure 2 The research model Source: developed for this research

Based on the research model above, six hypotheses can be stated as (1) H1: there is a positive relationship between Christian values and attitudes toward knowledge sharing; (2) H2: there is a positive relationship between attitudes toward knowledge sharing and intentions to share knowledge; (3) H3: there is a positive relationship between subjective norms regarding knowledge sharing and intention to share knowledge; (4) H4: there is a positive relationship between perceived behavioral control and intention to share knowledge; (5) H5: there is a positive relationship between intention to share knowledge and knowledge sharing behavior; (6) H6: Christian values moderate the relationship between attitude and intention to share knowledge. 


\section{RESEARCH METHOD}

Measurement. Constructs in the theory of planned behavior were adapted from Lin \& Lee (2004) and Lin (2007) and Christian values were adapted from Christian reference (hhtp://www.christianbiblereference.org/index.htm).

\section{Attitude toward Knowledge-Sharing}

Four items will be used to assess attitude toward knowledge-sharing. Those items are as follows: (1) encouraging knowledge-sharing with colleagues is an important component of the policy of my university, (2) encouraging knowledge-sharing with colleagues is a good idea, (3) encouraging knowledge-sharing with colleagues is valuable, and (4) encouraging knowledge-sharing with colleagues is beneficial.

\section{Subjective Norms}

Subjective norms will be measured through two items as follows: (1) my supervisor influences my decision think that I should share knowledge with colleagues, and (2) my colleagues influence my decision think that I should share knowledge with them.

\section{Perceived Behavioral Control}

Perceived behavioral control will be assessed through three items as follows: (1) my past experience has increases my confidence in my ability to make decisions encouraging employees to share knowledge with colleagues, (2) encouraging knowledge sharing with colleagues is within my control in my university, and (3) I am always likely to share knowledge.

\section{Intention}

Intention will be measured by using three items as follows: (1) I will try to share knowledge with my colleagues, (2) I plan to share knowledge with my colleagues, and (3) I intend to share knowledge with my colleagues.

\section{Sharing Behavior}

Sharing behavior is a self-stated rather than observed. Respondents indicated, on a 5-point scale (never-always), the extent to which they share knowledge with their colleagues. Three indicators were used to represent the variable. Those indicators such as follows: (1) I share knowledge obtained from education with each other, (2) I share knowledge obtained from training with each other, and (3) I share knowledge obtained informally (such as issues and new stories) with each other.

\section{Christian Values}

Christian values were assessed through ten items. Examples of the Christian values are: (1) worship only God, (2) respect all people, (3) be humble, and (4) forgive others.

\section{Survey}

A self-administrated questionnaire was used to collect data. The questionnaire was pre-tested in order to uncover biased or ambiguous questions before they are administered at large (Sekaran \& Bougie, 2010). In this research, the pretesting involved a group of respondents selected on a 
convenience basis (Sekaran \& Bougie, 2010). A total of 20 sets of questionnaires were distributed to full-time and part-time lecturer. The instrument then was refined after pretesting. Based on Azwar (1995), several indicators of research constructs were dropped because of the corrected item-total correlation was below 0.30 . Then, item-total statistics were again computed to achieve value greater than 0.3 . The reliability of each construct was as follows: Christian values $=0.922$; attitude toward knowledge sharing $=0.895$; subjective norms about knowledge sharing $=0.765$; perceived behavioral control $=0.781$; intentions to knowledge sharing $=0.874$; and knowledge sharing behavior $=0.937$. All the values were above 0.7, exceeding the common threshold values recommended by Hair et al. (2006).

\section{Sample and Questionnaire Administration}

Data was collected over a month period, using a convenience sample of 200 full-time and part-time faculty members in a private university. This research followed Hair et al. (2006) which recommended sample size is 200 , which provides a sound basis for estimation.

\section{Analysis Data}

A structural equation modeling was used to test the relationship between constructs. This method was used because SEM has ability to assess the relationships comprehensively (Hair et al., 2006). Maximum likelihood (ML) was applied as an appropriate estimation method in this research. The major reason was the method is robust to violation of the normality assumption (Tabachnick \& Fidell, 1996). However, on non-normal data, $\chi 2$ and standard error cannot be trusted (Bagozzi \& Baumgartner, 1994). Therefore, the ML estimation applied in this research used $\chi 2$ adjusted which termed as CMIN/DF (Steenkamp \& Van Trijp, 1991). For the overall fit of the model, this research several indices such as CMIN/DF, GFI, AGFI, and RMSEA as suggested by Giles (2002).

\section{RESULT}

\section{Response Rate}

A total of 200 questionnaires was distributed and collected from full-time and part-time lecturers in a private university. Of these, 127 samples can be used for further analysis, which constitutes a 63.5 per cent usable response rate.

\section{Reliability and Validity Assessments}

In assessing the psychometric properties of the instrument, issues of reliability and validity have been considered. First, reliability analyses were conducted. Table 1 shows the reliability of the measures. According to Hair et al. (2006), the generally agreed upon lower limit for Cronbach's alpha is 0.70 . The reliability (i.e., Cronbach's Alpha) of the scales of all variables ranged from 0.776 to 0.935 , proving evidence of internal consistency of the measures. 
Table 1 Construct reliability

\begin{tabular}{|c|c|c|c|}
\hline Construct & Items & $\begin{array}{l}\text { Cronbach } \\
\text { alpha }\end{array}$ & $\begin{array}{l}\text { Corrected Item - } \\
\text { Total Correlation }\end{array}$ \\
\hline \multirow[t]{2}{*}{ Attitudes } & & 0.776 & \\
\hline & $\begin{array}{l}\text { ATT1. Encouraging knowledge sharing with } \\
\text { colleagues is a good idea. } \\
\text { with colleagues is a good idea. } \\
\text { ATT2. Encouraging knowledge sharing with } \\
\text { colleagues is valuable. }\end{array}$ & 0.643 & 0.643 \\
\hline \multirow[t]{4}{*}{ Subjective Norms } & & 0.875 & \\
\hline & $\begin{array}{l}\text { SN1. My supervisor influences my decisions } \\
\text { that I should share knowledge with } \\
\text { colleagues. }\end{array}$ & & 0.714 \\
\hline & $\begin{array}{l}\text { SN2. My colleagues influences my decisions } \\
\text { that I should share knowledge with others. }\end{array}$ & & 0.837 \\
\hline & $\begin{array}{l}\text { SN3. Those who are important to me influence } \\
\text { my decisions that I should share knowledge } \\
\text { with colleagues. }\end{array}$ & & 0.730 \\
\hline \multirow{3}{*}{$\begin{array}{l}\text { Perceived Behavioral } \\
\text { Control }\end{array}$} & & 0.903 & \\
\hline & $\begin{array}{l}\text { PBC1. I have the resources in sharing knowledge } \\
\text { with colleagues }\end{array}$ & & 0.823 \\
\hline & $\begin{array}{l}\text { PBC2. I have the abilities in sharing knowledge } \\
\text { with colleagues }\end{array}$ & & 0.823 \\
\hline \multirow[t]{3}{*}{ Intentions } & & 0.921 & \\
\hline & $\begin{array}{l}\text { IN1. I plan to share knowledge with my } \\
\text { colleagues. }\end{array}$ & & 0.854 \\
\hline & $\begin{array}{l}\text { IN2. I intend to share knowledge with my } \\
\text { colleagues }\end{array}$ & & 0.854 \\
\hline \multirow[t]{3}{*}{ Behaviors } & & 0.903 & \\
\hline & $\begin{array}{l}\text { BEH1. My colleagues in my university share } \\
\text { knowledge obtained from their education. }\end{array}$ & & 0.825 \\
\hline & $\begin{array}{l}\text { BEH2. My colleagues in my university share } \\
\text { knowledge obtained from their training. }\end{array}$ & & 0.825 \\
\hline \multirow[t]{4}{*}{ Christian Values } & & 0.935 & \\
\hline & CV1. Worship only God & & 0.939 \\
\hline & CV2. Respect all people. & & 0.924 \\
\hline & CV3. Be humble & & 0.924 \\
\hline CV4. Be honest. & & 0.926 & \\
\hline $\begin{array}{l}\text { CV6. Be generous } \\
\text { with time and money } \\
\text { CV7. Practice what }\end{array}$ & CV5. Live in a moral live & 0.926 & 0.925 \\
\hline \multirow[t]{3}{*}{$\begin{array}{l}\text { you preach; don't be } \\
\text { hypocrite }\end{array}$} & & 0.926 & \\
\hline & CV8. Don't be self-righteous & & 0.932 \\
\hline & CV9. Don't hold a grudge & & 0.928 \\
\hline CV10. Forgive others & & 0.927 & \\
\hline
\end{tabular}

Source: analysis of field data

Having done the reliability tests, a factor analysis was run using Varimax rotation. Each scale was subjected to exploratory factor analysis loading on the dominant factor (at least 0.50 ) with a sum of the items in the factor explaining more that 50 per cent of the factor's variance (Table 2). Based on Gerbing \& Anderson (1988), confirmatory factor analysis (CFA) using maximum likelihood estimation procedures was performed for measure validation. Table 3 shows that the results indicate acceptable model fits. Table 3 also shows that all items significantly load on their corresponding constructs, demonstrating adequate convergent validity. 
Table 2 Exploratory Factor Analysis

\begin{tabular}{|c|c|c|c|c|c|c|}
\hline & Factor 1 & Factor 2 & Factor 3 & Factor 4 & Factor 5 & Factor 6 \\
\hline Attitude1 & & & & & & 0.801 \\
\hline Attitude2 & & & & & & 0.819 \\
\hline Subjective Norm1 & & & 0.862 & & & \\
\hline Subjective Norm2 & & & 0.928 & & & \\
\hline Subjective Norm3 & & & 0.872 & & & \\
\hline Perceived Behavioral & & & & & 0.917 & \\
\hline Control1 & & & & & & \\
\hline Perceived Behavioral & & & & & 0.892 & \\
\hline Control2 & & & & & & \\
\hline Intention 1 & & & & 0.944 & & \\
\hline Intention 2 & & & & 0.931 & & \\
\hline Behavior1 & & & 0.919 & & & \\
\hline Behavior2 & & & 0.895 & & & \\
\hline Christian value1 & 0.566 & & & & & \\
\hline Christian value2 & 0.813 & & & & & \\
\hline Christian value 3 & 0.832 & & & & & \\
\hline Christian value4 & 0.814 & & & & & \\
\hline Christian value 5 & 0.855 & & & & & \\
\hline Christian value6 & 0.853 & & & & & \\
\hline Christian value 7 & 0.826 & & & & & \\
\hline Christian value8 & 0.705 & & & & & \\
\hline Christian value9 & 0.830 & & & & & \\
\hline Christian value10 & 0.811 & & & & & \\
\hline
\end{tabular}

Table 3 Confirmatory factor analysis

\begin{tabular}{|c|c|c|}
\hline Item & Standardized loading & Critical Ratio (CR) \\
\hline \multicolumn{3}{|l|}{ Attitude } \\
\hline ATT1 & 0.906 & \\
\hline ATT2 & 0.716 & 7.030 \\
\hline \multicolumn{3}{|l|}{ Subjective Norm } \\
\hline SN1 & 0.770 & \\
\hline SN2 & 0.960 & 10.220 \\
\hline SN3 & 0.790 & 9.486 \\
\hline \multicolumn{3}{|l|}{ Perceived Behavioral Control } \\
\hline $\begin{array}{l}\mathrm{PBC1} \\
\mathrm{PBC} 2\end{array}$ & 0.873 & \\
\hline Intention & 0.943 & 0.879 \\
\hline \multicolumn{3}{|l|}{ IN1 } \\
\hline IN2 & 0.867 & \\
\hline \multirow{2}{*}{\multicolumn{3}{|c|}{ Behavior }} \\
\hline & & \\
\hline $\mathrm{BEH} 2$ & 0.860 & \\
\hline \multirow{2}{*}{\multicolumn{3}{|c|}{$\begin{array}{l}\text { Christian values } \\
\text { CV1 }\end{array}$}} \\
\hline & & \\
\hline CV2 & 0.587 & \\
\hline $\mathrm{CV} 3$ & 0.860 & 7.205 \\
\hline CV4 & 0.852 & 7.168 \\
\hline CV5 & 0.827 & 7.068 \\
\hline CV6 & 0.826 & 7.037 \\
\hline CV7 & 0.850 & 7.146 \\
\hline CV8 & 0.777 & 6.796 \\
\hline CV9 & 0.677 & 6.191 \\
\hline \multirow[t]{2}{*}{ CV10 } & 0.709 & 6.392 \\
\hline & 0.738 & 6.570 \\
\hline \multicolumn{3}{|l|}{$\begin{array}{l}\text { Goodness-of-fit statistics of the model } \\
X^{2}=206.884\end{array}$} \\
\hline \multicolumn{3}{|l|}{ Goodness-of-Fit Index $(\mathrm{GFI})=0.877$} \\
\hline \multicolumn{3}{|l|}{ Comparative Fit Index (CFI) $=0.978$} \\
\hline Root Mean Square Error of Approximation & & \\
\hline
\end{tabular}

Source: analysis of field data 
In order to provide support for discriminant validity, Pearson product-moment correlations among the study variables were computed. For this purpose, composite scores for each dimension were calculated by averaging scores representing that dimension. Table 4 provides the full set of correlations among the constructs of interest in this research. The highest correlation occurred between attitude toward knowledge sharing and intention to do knowledge sharing (0.467) and reversely, the lowest correlation was found between Christian values and subjective norms regarding knowledge sharing (-0.39). The results provide support for the discriminant validity of the scale (Anderson \& Gerbing, 1988).

Table 4 Correlations among constructs

\begin{tabular}{|c|c|c|c|c|c|c|}
\hline Construct & 1 & 2 & 3 & 4 & 5 & 6 \\
\hline 1. Attitude & 1 & & & & & \\
\hline 2. Subjective noms & $0.184^{*}$ & 1 & & & & \\
\hline 3. Perceived behavioral control & $0.434 * *$ & 0.107 & 1 & & & \\
\hline 4. Intention & $0.467 * *$ & 0.098 & $0.338 * *$ & 1 & & \\
\hline 5. Behavior (knowledge sharing) & 0.006 & 0.096 & -.090 & $0.229^{* *}$ & 1 & \\
\hline 6. Christian values & $0.275^{* *}$ & -.039 & $0.302^{* *}$ & $0.183 * *$ & 0.096 & 1 \\
\hline
\end{tabular}

Source: analysis of field data

\section{Hypotheses Testing Results}

Structural equation modeling was applied to estimate parameters of the structural model. The results show that the overall acceptability of the overall model was acceptable. Furthermore, most path coefficients were significant at the 0.05 significance level (Table 5).

Table 5 Structural Model Results

\begin{tabular}{|c|c|c|c|}
\hline Hypothesized Relationship & Estimate & C.R. & Conclusion \\
\hline $\begin{array}{l}\text { H1. Attitude toward knowledge sharing } \rightarrow \\
\text { intentions to knowledge sharing }\end{array}$ & 0.408 & 2.880 & Supported \\
\hline $\begin{array}{l}\text { H2. Subjective norms about knowledge sharing } \\
\rightarrow \text { intentions to knowledge sharing }\end{array}$ & 0.060 & 0.821 & Not Supported \\
\hline $\begin{array}{l}\text { H3. Perceived behavioral control to } \\
\text { knowledge sharing } \rightarrow \text { intentions } \\
\text { to knowledge sharing }\end{array}$ & 0.196 & 2.362 & Supported \\
\hline $\begin{array}{l}\text { H4. Intentions to knowledge sharing } \\
\rightarrow \text { knowledge sharing behavior }\end{array}$ & 0.347 & 3.754 & Supported \\
\hline $\begin{array}{l}\text { H5. Perceived behavioral control to } \\
\text { knowledge sharing } \rightarrow \text { knowledge } \\
\text { sharing behavior }\end{array}$ & -0.185 & -2.000 & $\begin{array}{l}\text { Not supported } \\
\text { (different direction) }\end{array}$ \\
\hline $\begin{array}{l}\text { H6. Christian values } * \text { attitude } \rightarrow \text { intention to } \\
\text { share knowledge }\end{array}$ & 0.050 & 0.350 & Not Supported \\
\hline $\begin{array}{l}\text { Goodness-of-fit statistics } \\
\text { of the model } X^{2}=4.102 \\
\text { Goodness-of-Fit Index }(\mathrm{GFI})=0.989 \\
\text { Comparative Fit Index (CFI) }=0.926 \\
\text { Root Mean Square Error of Approximation } \\
\qquad \text { (RMSEA) } \quad=0.054\end{array}$ & & & \\
\hline
\end{tabular}

Source: analysis of field data 
The first hypothesis predicted a positive relationship between attitude and intention to share knowledge. The results substantiated the hypothesis $(\mathrm{CR}=2.880)$. The second hypothesis predicted a positive relationship between subjective norms about knowledge sharing and intentions to share knowledge. Contrary to expectations, the results did not substantiated the hypothesis $(\mathrm{CR}=0.821)$. This research proposed that there was a positive relationship between perceived behavioral control and intention to share knowledge (hypothesis three). The result substantiated hypothesis three (CR = 2.362). Then, the fourth hypothesis proposed a positive relationship between intention to knowledge sharing and knowledge sharing behavior. The results supported the hypothesis $(\mathrm{CR}=3.754)$. The fifth hypothesis stated that there was a positive relationship between perceived behavioral control to knowledge sharing and knowledge sharing behavior. Table 5 showed that this hypothesis was not substantiated because the relationship yielded a standardized path coefficient of $-0.265(\mathrm{CR}=-2.000)$. In spite of its statistical significance, this result does not support hypothesis 5. Finally, the six hypotheses proposed that Christian values moderate the relationship between attitude and intention to share knowledge. However, the result did not substantiated the hypothesis $(\mathrm{CR}=0.350)$.

\section{DISCUSSION}

The objective of the present study was to extend and apply the theory of planned behavior to examine knowledge sharing behavior. The present study confirms that attitude affect intentions to knowledge sharing. Intention also affects knowledge sharing behavior. This study also confirms the relationship between perceived behavioral control and intention to share knowledge. However, there were three hypotheses that were not supported in this research. Those hypotheses were the positive relationship between subjective norms regarding knowledge sharing and intention to share knowledge, the positive relationship between perceived behavioral control and knowledge sharing behavior, and Christian values moderate the relationship between attitude and intention to share knowledge.

No relationship between subjective norms and behavioral intention was found in this study. Therefore, respondents' intention to share knowledge was not related with perceived social pressure from important referents. The finding was inconsistent with previous studies that applied TPB in understanding knowledge sharing behavior (e.g., Lin \& Lee, 2004). The inconsistency of the research could be a reflection of nature of the study sample. Specifically, this research used faculty members in a private university as study respondents. Based on exploratory research, this study found that two relevant referents for this study are head department and colleagues. However, findings from descriptive statistics show that head department was not considered as person that can affect respondents' intention to share knowledge (Table 7). According to Leenders (cited by Cheng et al., 2006), the more frequent and intense the communication is between and individual and his or her important others, the more likely it is that an individual will adopts the beliefs from them. However, because of more management load and teaching load for the head department may result in infrequently contact or talk with faculty members. Table 6 also show that colleagues and others perceived important referents for the respondents were also not really considered as person that can affect respondents' intention to share knowledge.

Table 6 Descriptive statistics for indicators of subjective norms

\begin{tabular}{|l|r|r|r|r|r|}
\hline & \multicolumn{1}{|c|}{ Descriptive Statistics } \\
\hline NS1 & 127 & Minimum & Maximum & Mean & Std. Deviation \\
NS2 & 127 & 1.00 & 7.00 & 4.1969 & 1.65730 \\
NS3 & 127 & 1.00 & 7.00 & 4.5276 & 1.65149 \\
Valid N (listwise) & 127 & & 7.00 & 4.7402 & 1.70533 \\
\hline
\end{tabular}

Legend: NS 1 (head department)

NS2 (colleagues) 


\section{NS3 (all important people) \\ Source: analysis of field data}

This study shows that perceived behavioral control was significantly related to knowledge sharing behavior, however, in a different direction (i.e., negative direction). In other words, the higher the perceived behavioral control, the lower knowledge sharing behavior. Perceived behavioral control refers to people's appraisal of their ability to perform the behavior. The estimated standardized coefficient for the relationship between perceived behavioral control to knowledge sharing and knowledge sharing behavior was $-0.195(\mathrm{CR}=-2.034)$. This indicates that the higher their ability to perform the behavior (that is knowledge sharing), the lower their behavior to share knowledge. This is may be because the context of the research: knowledge sharing. Again, as stated before, knowledge is important, as an old maxim states that "Knowledge is power." In other words, some people may not share their knowledge because they think that knowledge should be for them.

Christian values were also found not as a moderating variable in the relationship between attitude and intention to share knowledge. In other words, Christian values do not interact with attitude in affecting intention to share knowledge. However, one study by Sihombing (2009) found that Christian values does affect attitude toward knowledge sharing. Therefore, Christian values are best treated as an antecedent variable rather than a moderating variable.

\section{CONCLUSIONS}

The main objectives of this study are to test the theory of planned behavior in the context of knowledge sharing and then understand the moderating role of Christian values in the relationship between attitude and intention to share knowledge. The results showed those lecturers' attitudes toward knowledge sharing also significantly impacted behavioral intention. The results also show that another factor which impact intention to share knowledge is perceived behavioral control. Then, behavioral intention significantly impacted knowledge sharing behavior. However, there are three hypotheses which are not substantiated in this research. First, subjective norms about knowledge sharing and perceived behavioral control to knowledge sharing did not significantly influence lecturers' behavioral intention. Second, this research found that perceived behavioral control to knowledge sharing significantly impact knowledge sharing behavior in a different direction. In other words, it was expected the relationship between perceived behavioral control and knowledge sharing was positive. However, the result of this research pointed out that the direction was negative and significant. Third, this research also found that Christian values did not moderate the relationship between attitude and intention to share knowledge. Finally, there are two main limitations of this study. First, this research used self-reports of sharing knowledge were obtained, rather than actual sharing knowledge behavior. Second, this research tests the fit of the model within a single university.

\section{REFERENCES}

Anderson, J. C., \& Gerbing, D. W. (1988). Structural Equation Modeling in Practice: a Review and Recommended Two-Step Approach. Psychological Bulletin, May, 411-423.

Ajzen, I. (1988). Attitudes, Personality, and Behavior. Britain: Open University Press.

Ajzen, I., \& Fishbein, M. (1980). Understanding Attitudes and Predicting Social Behavior, New Jersey: Prentice-Hall, Inc. 
Ajzen, I. (1991). The Theory of Planned Behavior. Organizational Behavior and Human Decision Processes, 50, 179-211.

Ajzen, I. (2001). Nature and Operation of Attitude. Annual Review Psychology, 52, 27-58.

Arnould, E., Price, L., \& Zinkhan, G. (2002). Consumers. NY: McGraw-Hill.

Azwar, S. (1995). Sikap Manusia: Teori dan Pengukurannya, Edisi ke 2, Yogyakarta: Pustaka Pelajar.

Bagozzi, R., \& Baumgartner, H. (1994). The Evaluation of Structural Equation Models and Hypothesis Testing, Principles of Marketing Research, R. Bagozzi (ed.), Cambridge, pp. 386422, 1994.

Bartol, K. M., \& Srivastava, A. (2002). Encouraging knowledge sharing: the role of organizational reward systems. Journal of Leadership and Organization Studies, 9, 1, 64-76.

Beatty, S. E., Homer, P. M., \& Kahle, L. R. (1988). Problems with VALS in International Marketing Research: an Example from an Application of the Empirical Mirror Technique. Advances in Consumer Research, 15, 375-380.

Breslin, C., Li, S., Tupker, E., \& Sdao-Jarvie, K. (2001). Application of the Theory of Planned Behavior to Predict Research Dissemination: a Prospective Study Among Addiction Counselors. Science Communication, 22, 423-437.

Burgess, D. (2005). What Motivates Employees to Transfer Knowledge Outside Their Work Unit? Journal of Business Communication, 42, 4, 324-348.

Chan, A. M. (2009). Measuring Cross-Cultural Values: a Qualitative Approach. International Review of Business Research Papers, 5, 6, 323-337.

Cheng, S., Lam, T., \& Hsu, C. H. C. (2006). Negative Word-Of-Mouth Communication Intention: an Application of the Theory of Planned Behavior. Journal of Hospitality \& Tourism, 30,1, 95116.

Cheung, S. F., Chan, D. K. S., \& Wong, Z. S. Y. (1999). Reexamining the Theory of Planned Behavior in Understanding Wastepaper Recycling. Environment and Behavior, 31, 587-612.

Cordano, M., \&Frieze, I. H. (2000). Pollution Reduction Preferences of U.S. Environmental Managers: Applying Ajzen's Theory of Planned Behavior, Academy of Management Journal 43, 624-641. doi:10.2307/1556358

Cornner, M., \& Abraham, C. (2001).Conscientiousness and the Theory of Planned Behavior: Toward a Mode Complete Model of the Antecedents of Intentions and Behavior. Personality and Social Psychology Bulletin, 27, 11, 1547-1561.

Davenport, T. H., \& Prusak, L. (1998). Working Knowledge: How Organizations Manage What They Know. Boston: Harvard Business School Press.

de Mooij, M. K. (2004). Consumer Behavior and Culture: Consequences for Global Marketing and Advertising. Thousand Oaks, CA: Sage. 
De Vries, R. R., Van Den Hooff, B., \& De Ridder, J. A. (2006). Explaining Knowledge Sharing: the Role of Team Communication Styles, Job Satisfaction, and Performance Beliefs, Communication Research, 33, 2, 115-135.

Delener, N. (1994). Religious Contrast in Consumer Decision Behavior Patterns: Their Dimensions and Marketing Implications. European Journal of Marketing, 28, 5, 36-53.

Dharmmesta, B. S. \& Khasanah, U. (1999). Theory of Planned Behavior: An Application to Transport Service Consumers, Gadjah Mada International Journal of Business, 1, 1, 83-96.

East, R. (2000). Complaining as Planned Behavior, Psychology \& Marketing, 17 (12), 1077-98.

George, J. F. (2002) Influences on the intent to make Internet purchases. Internet Research 12(2): 165180.

Gerbing, D. W., \& Anderson, J. C. (1988). An Updated Paradigm for Scale Development Incorporating Unidimensionality and Its Assessment. Journal of Marketing Research, 25, May, 307-319.

Giles, D. (2002). Advanced Research Methods in Psychology. NY: Routledge.

Gurteen, D. (1999). Creating a Knowledge Sharing. Knowledge Management Magazine, 2, 5, February.

Hair, J. F., Black, W. C., Babin, B. J., Anderson, R. E., \& Tatham, R. L. (2006). Multivariate Data Analysis. New Jersey: Pearson Education, Inc.

Halal, W. E. (2008). The Logic of Knowledge: Making Sense of the New Principles That Govern Organizations and Economics. Available at http://home.gwu.edu/uhalal/Articles/Logic.pdf

Hendriks, P. (1999). Why Share Knowledge? The influence of ICT on the Motivation for Knowledge Sharing. Knowledge and Process Management, 6, 2, 91-100.

Hofstede, G. (1994). Cultures and Organizations: Software of the Mind, London: Harper- Collins Publishers.

Homer, P. M., \& Kahle, L.R. (1988). A Structural Equation Test of the Value-Attitude-Behavior Hierarchy, Journal of Personality and Social Psychology, 54, 4, 638- 646.

Ipe, M. (2003). Knowledge Sharing in Organizations: a Conceptual Framework. Human Resource Development Review, 2, 4, 337-359.

Ismail, A., Alli, N., \& Abdullah, M. M. (2009a). Perceive Value as a Moderator on the Relationship Between Service Quality Features and Customer Satisfaction. International Journal of Business and Management, 4, 2, 71-79.

Ismail, A., Dousin, A., Girardi, A., Ahmad, Z. A., Shariff, M. N. M., Majid, A. B., Abdullah, M. M. \& Ibrahim, Z. (2009b). Empirically Testing the Relationship Between Income Distribution, Perceived Value Money, and Pay Satisfaction. Intangible Capital, 5, 3, 235-258.

Jusmaliani, \& Nasution, H. (2009). Religiosity Aspect in Consumer Behavior: Determinants of Halal Meat Consumption. Asean Marketing Journal, 1, 1, 5-17.

Kalafatis, S.P., Pollard, M., East, R. and Tsogas, M.H., 1999, "Green Marketing and Ajzen's Theory of Planned Behavior," Journal of Consumer Marketing, 16, 5, 441-460. 
Kanler, C., \& Todd, S. (1998). The Motivation to Purchase pension: An Application of Planned Behavior Theory, Kingston University Paper Series, http://business.king.c.uk/papers/opres32

Kokkinaki, F. (1999). Predicting Product Purchase and Usage: The Role of Perceived Control, Past Behavior and Product Involvement, Advances in Consumer Research, 26, 576-583.

Lin, H. (2007). Effects of Extrinsic and Intrinsic Motivation on Employee Sharing Intentions, Journal of Information Science, 33, 3, 135-149.

Lin, Q., \& Lee, J. (2004). Consumer information search when making investment decisions. Financial Services Review, 13(4), 319-332.

Lindridge, A. (2005). Religiosity and the Construction of a Cultural-Consumption Identity. Journal of Consumer Marketing, 22, 3, 142-151.

Lombaerts, H. (2003). Christian Moral Values and Educational Theories. Acta Paedagogica Vilnensia, $10,1-13$.

Maurer, T. J., \& Palmer, J. K. (1999). Management development intentions following feedback: Role of perceived outcomes, social pressures, and control. Journal of Management Development, $18,733-751$.

Morris, M. G., \& Venkatesh, V. (2000). Age differences in technology adoption decisions: Implications for a changing workforce. Personnel Psychology. 53:375-403. doi: $10.1111 / \mathrm{j} .1744-6570.2000 . t b 00206 . x$

Oreg, S., \& Katz-Gerro, T. (2006). Predicting Proenvironmental Behavior Cross-Nationally: Values, the Theory of Planned Behavior, and Value-Belief-Norm Theory. Environment \& Behavior, $38,4,462-483$.

Pai, J. (2006). An Empirical Study of the Relationship between Knowledge Sharing and IS/II Strategic Planning (ISSP). Management Decision, 44, 1, 105-122.

Riady, J. (2008). Merging Faith and Work in today’s Context. Campus Asia, 2,6, 128-129.

Rokeach, M. (1973). The Nature of Human Values. NY: Free Press.

Scaperlanda, A. (1993). Christian Values and Economic Ethics. International Journal of Social Economics, 20, 10, 4-12.

Sekaran, U., \& Bougie, R. (2010). Research Methods for Business: a Skill Building Approach (4th ed.). New York: John Wiley \& Sons.

Sihombing, S. O. (2009). Does Faith Matter? Extending the Theory of Planned Behavior with Christian Values to Predict Knowledge Sharing Behavior. Proceedings of the $4^{\text {th }}$ International Conference on Business and Management Research (ICMBR), Bali: Universitas Indonesia.

Steenkamp, J. E. M., \& Van Trijp, H. C. M. (1991). The Use of LISREL in Validating Marketing Construct. International Journal of Research in Marketing, 8, 283-299.

Stern, P. C., Dietz, T., Abel, T., Guagnano, G. A., \& Kalof, L. (1999). A Value-Belief-Norm Theory of Support for Social Movements: the Case of Environmentalism. Human Ecology Review, 6, 81-97. 
Tabachnick, B. G., \& Fidell, L. S. (1996). Using Multivariate Statistics (3rd ed.). NY: Harper Collins College Publishers.

Tarkiainen, A., \& Sundqvist, S. (2005). Subjective Nors, Attitudes and Intentions of Finnih Consumers in Buying Organic Food, British Food Journal, 107, 11, 808-822.

Thompson, N.J., \& Thompson, K.E. (1996). Reasoned Action Theory: an Application to Alcohol-Free beer, Journal of Marketing Practice: Applied Marketing Science, 2, 2, 35-48.

Wang, Z., Rao, C. P., \& D'Auria. (1994). A comparison of the Rokeach Value Survey (RVS) in China and the United States. Asia Pacific Advances in Consumer Research, 1, 185-190.

Wells, W.D., \& Prensky, D. (1996). Consumer Behavior, NY: John Wiley \& Sons.

Yang, C., \& Chen, L. (2007). Can Organizational Knowledge Capabilities Affect Knowledge Sharing Behavior? Journal of Information Science, 33, 1, 95-109.

Yuen, T. J., \& Majid, M. S. (2007). Knowledge-Sharing Patterns of Undergraduate Students in Singapore. Library Review, 56, 6, 485-494.

Zetterberg, H. L. (1998). ESOMAR Handbook of Marketing and Opinion Research, Chapter 29. Colin McDonald and Phyllis Vangelder (eds.) (4th ed.). Amsterdam: City University of Stockholm and ValueScope AB. 